\title{
Stimulation of an immune system by different types of allergens causes seasonal (late spring and summer) factors to increase probability of allergic rhinitis symptoms. The Epidemiology of Allergic Diseases in Poland (ECAP) survey: part two
}

\author{
Andrzej Namysłowski ${ }^{1}$, Agnieszka Lipiec ${ }^{1}$, Wojciech Zieliński ${ }^{1,2}$, Filip Raciborski ${ }^{1}$, Aneta Tomaszewska ${ }^{1}$, \\ Artur Walkiewicz ${ }^{1}$, Piotr Samel-Kowalik ${ }^{1}$, Oksana Wojas ${ }^{1}$, Barbara Piekarska ${ }^{1}$, Bolesław Samoliński ${ }^{1}$
}

${ }^{1}$ Department of the Prevention of Environmental Hazards and Allergology, Medical University of Warsaw, Warsaw, Poland ${ }^{2}$ Department of Econometrics and Statistics, Warsaw University of Life Sciences, Warsaw, Poland

Adv Dermatol Allergol 2021; XXXVIII (3): 384-388

DOI: https://doi.org/10.5114/ada.2021.107925

\begin{abstract}
Introduction: Specific immunoglobulins $\mathrm{E}(\mathrm{s} / \mathrm{gE})$ are important parameters to estimate severity of allergic diseases. Aim: To determine the relationship between the concentration of slgE antibodies in serum and clinical outcome of allergic diseases.

Material and methods: The concentration of slgE antibodies against allergens Dermatophagoides pteronyssinus, cat dander, Timothy grass, Alternaria alternata were determined in serum of 4077 respondents randomly selected from 9 regions (ECAP study). Positive results of slgE $(\geq 0.35 \mathrm{IU} / \mathrm{ml})$ were correlated with answers in ECRHSII and ISAAC questionnaires.

Results: IgE antibodies are more frequently detected in respondents aged over 4 years when they had their first attack of asthma (cat dander $p<0.05$, Timothy grass $p<0.05$ ). IgE antibodies are less frequently detected in respondents aged over 29 years when they had the first allergic rhinitis symptoms as compared to respondents aged $0-19$ years when they had the first allergic rhinitis symptoms $(p<0.05$ to $p<0.001)$. Among respondents showing allergic rhinitis symptoms, IgE antibodies are more frequently detected in respondents showing those symptoms from May to August $(p<0.05$ to $p<0.005)$.

Conclusions: The first attack of asthma appears later mainly in patients whose immune systems are more strongly stimulated by allergens. Development of allergic rhinitis in patients aged over 29 years presumably needs weaker stimulation of their immune systems by allergens than in patients aged 0-19 years. Stimulation of an immune system by different types of allergens modifies its response in such a way that seasonal (late spring and summer) factors increase probability of allergic rhinitis symptoms.
\end{abstract}

Key words: specific IgE, asthma, allergic rhinitis, epidemiology, ECAP.

\section{Introduction}

Epidemiological studies from the last decades demonstrate an increase in the incidents of allergic rhinitis and asthma [1]. They are currently the diseases of a major prevalence and morbidity rate for people less than 30 years old, suffering from non-infectious chronic dis- eases [2-5]. Identifying the factors responsible for allergic rhinitis and asthma has been an aim of many studies. A broad survey called Epidemiology of Allergic Diseases in Poland (ECAP) proved epidemiological significance of allergic rhinitis and asthma in Poland and great diversity of allergy risk factors, sensitization to inhalation allergens among them [6-9]. Determination of specific IgE in

Address for correspondence: Agnieszka Lipiec MD, PhD, Department of the Prevention of Environmental Hazards and Allergology, Medical University of Warsaw, 1a Banacha St, 02-507 Warsaw, Poland, phone: +48 22599 20 39, e-mail: alipiec@wum.edu.pl Received: 21.11.2019, accepted: 1.12.2019. 
serum of the respondents, the most reliable method to evaluate allergic hypersensitivity [10, 11], has been the continuation of the ECAP study [12].

\section{Aim}

Aim of the study was to determine the relationship between the concentration of specific IgE antibodies in serum and clinical outcome of allergic diseases.

\section{Material and methods}

The quantitative data presented in the article were collected as part of the Epidemiology of Allergic Diseases in Poland (ECAP) project and its continuation. The ECAP comprised two main phases: (i) a questionnaire-based study (Computer-Assisted Personal Interview, CAPI); (ii) a complementary clinical assessment (spirometry with bronchodilator challenge, skin-prick tests, peak nasal inspiratory flow, and blood sampling for genetic and immune tests). Eighteen thousand six hundred and seventeen individuals from 8 cities (with a population in excess of 150 000) and one rural region took part in the study (phase one). The sample was drawn (by a stratified cluster sampling method) from a personal identity number (PESEL) database (maintained by the Minister of Interior and Administration). Four thousand seven hundred eighty-three respondents were randomly selected and examined by allergists (phase two of the study). Blood from 4077 respondents was collected, the concentration of IgE antibodies against allergens d1 (Dermatophagoides pteronyssinus), e1 (cat dander), g6 (Timothy grass), m6 (Alternaria alternata) was determined in serum, using the reference method CAP (Phadia reagents, UniCAP 100 laboratory system). The concentration of IgE antibodies of at least $0.35 \mathrm{lU} / \mathrm{ml}$ (classes 1-6) was considered
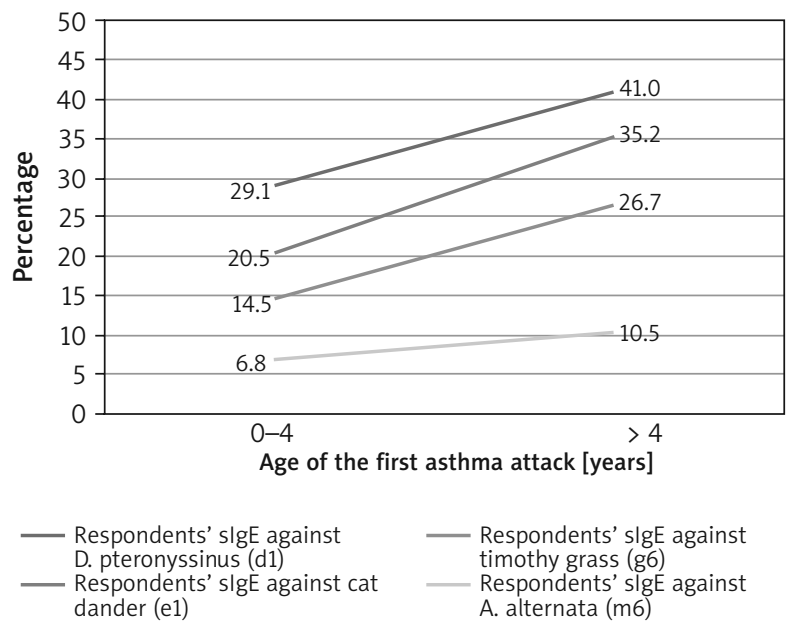

Figure 1. Percentage of respondents with slgE concentration $\geq 0.35 \mathrm{IU} / \mathrm{ml}$ (classes 1-6) in comparison to early and late first attack of asthma (0-4 years, over 4 years). Serum of respondents aged 6-7 years, 13-14 years, 20-44 years positive. The IgE-determined respondents included 2223 females and 1854 males. 1026 respondents were aged 6-7 years, 1053 respondents were aged 13-14 years, 1898 respondents were adults. An exact methodology of the ECAP survey is described at www.ecap.pl [12] and in the Polish Journal of Allergology [13].

The results of IgE antibodies determination were correlated to answers to these questions:

- How old were you when you had your first attack of asthma?

- How old were you when you had your most recent attack of asthma?

- Have you had an attack of asthma in the last 12 months?

- How many attacks of asthma have you had in the last 12 months?

- How old were you when you first had hay fever or nasal allergy?

- In which months of the year did a problem with sneezing or a runny or blocked nose occur when you did not have a cold or flu in the last 12 months?

- Have you ever had anaphylactic shock not caused by food allergy or drugs?

- Do you get angioneurotic oedema (swelling of e.g. hands or lips)?

The study was approved by the institutional Bioethics Committee.

The study was performed as part of the research grant from the National Science Centre (Poland), 2011/01/B/NZ7/05289.

\section{Statistical analysis}

The aim of the statistical analysis was to compare proportions of people with a high level of immunoglobulin in two groups. The classical approximate test for com-

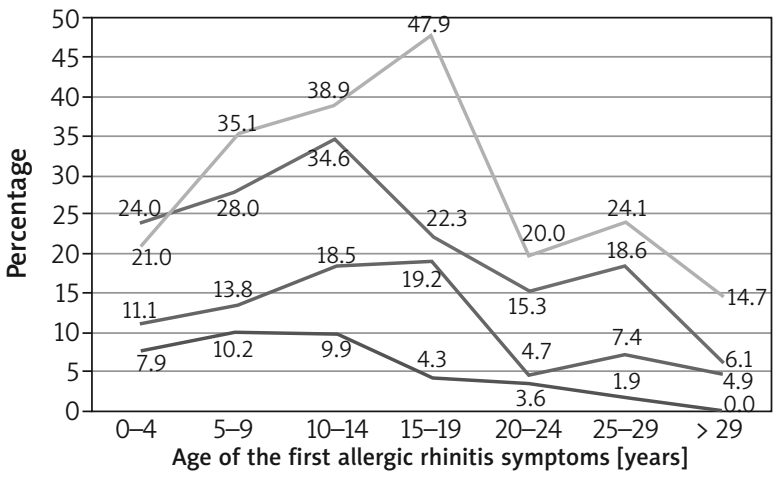

$\begin{array}{ll}\text { Respondents' slgE against } & \text { Respondents' slgE against } \\ \text { D. pteronyssinus (d1) } & \text { timothy grass (g6) } \\ \text { Respondents' slgE against cat } & \text { Respondents' slgE against } \\ \text { dander (e1) } & \text { A. alternata (m6) }\end{array}$

Figure 2. Percentage of respondents with slgE concentration $\geq 0.35 \mathrm{IU} / \mathrm{ml}$ (classes 1-6) in comparison to age of the first allergic rhinitis symptoms (declaration based on the questionnaire). Serum of respondents aged 6-7 years, 13-14 years, 20-44 years 
parison of two proportions was applied [14]. If calculated p-value was smaller than 0.05 , the statistically significant difference between investigated proportions was recognised. Otherwise, the fractions of people with a high level of immunoglobulin in investigated groups may be treated as similar. Calculations were performed using the statistical package Statistica (Statistica, Tulsa, Oklahoma, US).

\section{Results}

IgE antibodies are more frequently detected in respondents aged over 4 years when they had their first attack of asthma ("0-4 years" versus "over 4 years": D. pteronyssinus $p<0.1$, cat dander $p<0.05$, Timothy grass $p<0.05)$ (Figure 1 ).

IgE antibodies are less frequently detected in respondents aged over 29 years when they had the first allergic rhinitis symptoms as compared to respondents aged 0-19 years when they had the first allergic rhinitis symptoms (Figure 2). Relating to all allergens, numerous statistically significant differences were identified ( $p<$ 0.05 to $p<0.001$ ), comparing groups aged $0-4$ years, 5-9 years, 10-14 years, 15-19 years to a group aged over 29 years.

Among respondents showing allergic rhinitis symptoms in the last 12 months, IgE antibodies are more frequently detected in respondents showing those symptoms from May to August (D. pteronyssinus: June $p<0.05$, July $p<0.01$, August $p<0.1$; cat dander: May $p<0.005$, June $p<0.001$, July $p<0.001$, August $p<0.005$; Timothy grass: May $p<0.001$, June $p<0.001$, July $p<0.001$, August $p<0.001$; A. alternata: June $p<0.05$, July $p<0.001$, August $p<0.05$ ) (Table 1, Figure 3).

Among respondents showing allergic rhinitis symptoms in the last 12 months, relating to an allergen Timothy grass, IgE antibodies are less frequently detected in respondents showing those symptoms from September to March (January $p<0.001$, February $p<0.001$, March

Table 1. Number (percentage) of respondents with slgE concentration $\geq 0.35 \mathrm{IU} / \mathrm{ml}$ (classes 1-6) among respondents showing allergic rhinitis symptoms in the last 12 months (May-August)

\begin{tabular}{|c|c|c|c|c|c|}
\hline \multirow[t]{2}{*}{ Month } & \multicolumn{5}{|c|}{ Respondents' slgE against } \\
\hline & D. pteronyssinus (d1) & Cat dander (e1) & Timothy grass (g6) & A. alternata (m6) & $N(100 \%)$ \\
\hline May (yes) & $207(23.2 \%)$ & $112(12.5 \%)$ & $229(25.6 \%)$ & $55(6.2 \%)$ & 894 \\
\hline May (no) & $129(21.2 \%)$ & $46(7.6 \%)$ & $91(15.0 \%)$ & $30(4.9 \%)$ & 608 \\
\hline June (yes) & $193(25.0 \%)$ & 105 (13.6\%) & 239 (31.0\%) & $54(7.0 \%)$ & 771 \\
\hline June (no) & $143(19.6 \%)$ & $53(7.3 \%)$ & $81(11.1 \%)$ & $31(4.2 \%)$ & 731 \\
\hline July (yes) & $166(25.7 \%)$ & $97(15.0 \%)$ & 204 (31.6\%) & $53(8.2 \%)$ & 647 \\
\hline July (no) & 170 (19.9\%) & $61(7.1 \%)$ & $116(13.6 \%)$ & $32(3.7 \%)$ & 855 \\
\hline August (yes) & $138(25.1 \%)$ & 74 (13.5\%) & $144(26.2 \%)$ & $41(7.5 \%)$ & 550 \\
\hline August (no) & $198(20.8 \%)$ & $84(8.8 \%)$ & $176(18.5 \%)$ & $44(4.6 \%)$ & 952 \\
\hline
\end{tabular}

BOLD indicates the statistical significant difference.

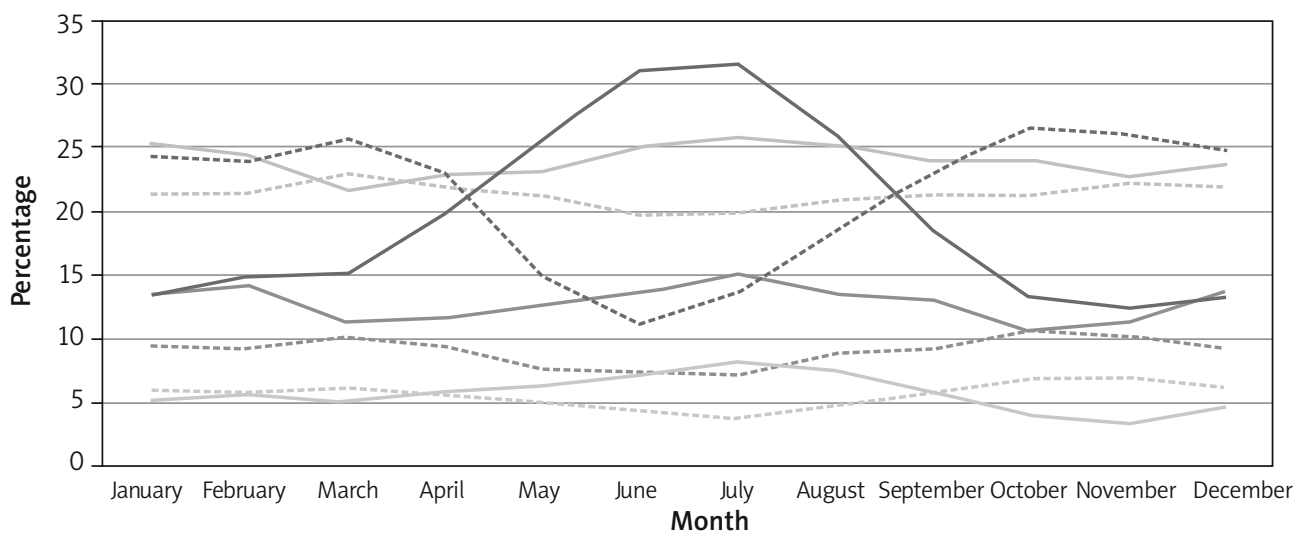

\footnotetext{
-Respondents' slgE against D. pteronyssinus (d1), symptoms in this month -Respondents' slgE against cat dander (e1), symptoms in this month

Respondents' slgE against D. pteronyssinus (d1), no symptoms in this month -- Respondents' slgE against cat dander (e1), no symptoms in this month -Respondents' slgE against timothy grass (g6), symptoms in this month - --- Respondents' slgE against timothy grass (g6), no symptoms in this month -Respondents' slgE against A. alternata (m6), symptoms in this month

Respondents' slgE against A. alternata (m6), no symptoms in this month
}

Figure 3. Percentage of respondents with slgE concentration $\geq 0.35 \mathrm{IU} / \mathrm{ml}$ (classes 1-6) among respondents showing allergic rhinitis symptoms in the last 12 months 
Table 2. Number (percentage) of respondents with slgE concentration $\geq 0.35 \mathrm{IU} / \mathrm{ml}$ (classes 1-6) among respondents showing allergic rhinitis symptoms in the last 12 months (January-April and September-December)

\begin{tabular}{lccccc}
\hline \multirow{2}{*}{ Month } & \multicolumn{5}{c}{ Respondents' slgE against } \\
\cline { 2 - 6 } & D. pteronyssinus (d1) & Cat dander (e1) & Timothy grass (g6) & A. alternata (m6) & $N(100 \%)$ \\
\hline January (yes) & $104(25.3 \%)$ & $55(13.4 \%)$ & $55(13.4 \%)$ & $21(5.1 \%)$ & 411 \\
\hline January (no) & $232(21.3 \%)$ & $103(9.4 \%)$ & $265(24.3 \%)$ & $64(5.9 \%)$ & 1091 \\
\hline February (yes) & $106(24.4 \%)$ & $61(14.1 \%)$ & $64(14.8 \%)$ & $24(5.5 \%)$ & 434 \\
\hline February (no) & $230(21.5 \%)$ & $97(9.1 \%)$ & $256(24.0 \%)$ & $61(5.7 \%)$ & 1068 \\
\hline March (yes) & $134(21.7 \%)$ & $70(11.3 \%)$ & $93(15.1 \%)$ & $31(5.0 \%)$ & 618 \\
\hline March (no) & $202(22.9 \%)$ & $88(10.0 \%)$ & $227(25.7 \%)$ & $54(6.1 \%)$ & 884 \\
\hline April (yes) & $179(22.8 \%)$ & $91(11.6 \%)$ & $155(19.8 \%)$ & $45(5.7 \%)$ & 784 \\
\hline April (no) & $157(21.9 \%)$ & $67(9.3 \%)$ & $165(23.0 \%)$ & $40(5.6 \%)$ & 718 \\
\hline September (yes) & $138(24.0 \%)$ & $74(12.9 \%)$ & $106(18.5 \%)$ & $33(5.8 \%)$ & 574 \\
\hline September (no) & $198(21.3 \%)$ & $84(9.1 \%)$ & $214(23.1 \%)$ & $52(5.6 \%)$ & 928 \\
\hline October (yes) & $141(24.1 \%)$ & $61(10.5 \%)$ & $77(13.2 \%)$ & $23(3.9 \%)$ & 584 \\
\hline October (no) & $195(21.2 \%)$ & $97(10.6 \%)$ & $243(26.5 \%)$ & $62(6.8 \%)$ & 918 \\
\hline November (yes) & $118(22.7 \%)$ & $59(11.3 \%)$ & $64(12.3 \%)$ & $17(3.3 \%)$ & 521 \\
\hline November (no) & $218(22.2 \%)$ & $99(10.1 \%)$ & $256(26.1 \%)$ & $68(6.9 \%)$ & 981 \\
\hline December (yes) & $104(23.7 \%)$ & $60(13.7 \%)$ & $58(13.2 \%)$ & $20(4.6 \%)$ & 439 \\
\hline December (no) & $232(21.8 \%)$ & $98(9.2 \%)$ & $262(24.7 \%)$ & $65(6.1 \%)$ & 1063 \\
\hline
\end{tabular}

$p<0.001$, September $p<0.05$, October $p<0.001$, November $p<0.001$, December $p<0.001$ ) (Table 2, Figure 3).

\section{Discussion}

A broad ECAP survey proved epidemiological significance of allergic rhinitis and asthma in Poland and great diversity of allergy risk factors. Determination of specific IgE in serum of the respondents, the most reliable method to evaluate allergic hypersensitivity, has been the continuation of ECAP. The aim of the study described in this article was to determine the relationship between the concentration of specific IgE antibodies in serum and clinical outcome of allergic diseases.

IgE antibodies are more frequently detected in respondents aged over 4 years when they had their first attack of asthma. This results, most likely, from a greater tendency to develop asthma as clinical outcome of allergic diseases, in the first years of human life. The first attack of asthma appears later mainly in patients whose immune systems are more strongly stimulated by allergens (increased production of specific lgE) - obviously if the allergy also appears later in life. In a study by Antó et al., atopy was found to increase the risk of new-onset asthma in middle-aged adults; among the atopics, total IgE and sensitization to cat were independently related to the risk of new-onset asthma [15]. In a study by Jaakkola et al., atopy as a risk factor for asthma is less common with increasing age [16]. One of the possible explanations for the result (respondents aged over 4 years) is that allergens might have, within the first year of life, a protective effect on asthma $[17,18]$. On the other hand, IgE antibodies are less frequently detected in respondents aged over 29 years when they had the first allergic rhinitis symptoms as compared to respondents aged 0-19 years when they had the first allergic rhinitis symptoms. Development of allergic rhinitis in patients aged over 29 years presumably needs weaker stimulation of their immune systems by allergens than in patients aged 0-19 years. In a study by Ciprandi et al., elderly allergic rhinitis patients seem to have a different phenotype/endotype in comparison with adult allergic rhinitis ones, characterized by milder symptoms, lower lgE production, and less sensitizations [19]. Among respondents showing allergic rhinitis symptoms in the last 12 months, IgE antibodies are more frequently detected in respondents showing those symptoms from May to August. Stimulation of an immune system by different types of allergens modifies its response in such a way that seasonal (late spring and summer) factors, most probably pollen allergens, increases probability of allergic rhinitis symptoms. In a study by Zolkipli et al., allergen immunotherapy significantly reduced sensitization to other allergens [20]. A series of studies evidenced that allergen-specific immunotherapy, with one or two allergen extracts, may be effective in polysensitized patients [21]. Among respondents showing allergic rhinitis symptoms in the last 12 months, IgE antibodies against Timothy grass are less frequently detected in respondents showing those symptoms from September to March. 
The expected relationship between the concentration of specific lgE antibodies in serum and clinical outcome of allergic rhinitis reflects time limited influence of the allergen on respondents. In a study by Rolinck-Werninghaus et al., baseline specific grass pollen IgE is associated with symptom severity during the pollen season in children with seasonal allergic rhinitis [22].

\section{Conclusions}

The first attack of asthma appears later mainly in patients whose immune systems are more strongly stimulated by allergens. Development of allergic rhinitis in patients aged over 29 years presumably needs weaker stimulation of their immune systems by allergens than in patients aged 0-19 years. Stimulation of an immune system by different types of allergens modifies its response in such a way that seasonal (late spring and summer) factors, most probably pollen allergens, increases probability of allergic rhinitis symptoms.

\section{Conflict of interest}

The authors declare no conflict of interest.

\section{References}

1. Asher MI, Montefort S, Björkstén B, et al. Worldwide time trends in the prevalence of symptoms of asthma, allergic rhinoconjunctivitis, and eczema in childhood: ISAAC Phases One and Three repeat multicountry cross-sectional surveys. Lancet 2006; 368: 733-43.

2. European Allergy White Paper, The UCB Institute of Allergy. Allergic diseases as a public health problem in Europe. UCB Institute of Allergy. Brussels, Belgium 1997.

3. Leynaert B, Neukirch C, Kony S, et al. Association between asthma and rhinitis according to atopic sensitization in a population-based study. J Allergy Clin Immunol 2004; 113: 86-93.

4. Bousquet J, Schünemann HJ, Samolinski B, et al. Allergic rhinitis and its impact on asthma (ARIA): achievements in 10 years and future needs. J Allergy Clin Immunol 2012; 130: 1049-62.

5. Van Cauwenberge P, Watelet JB, Van Zele T, et al. Spreading excellence in allergy and asthma: the Gallen Project. Allergy 2005; 60: 858-64.

6. Samoliński B, Sybilski A, Raciborski F, et al. Występowanie astmy oskrzelowej u dzieci, młodzieży i młodych dorosłych w Polsce w świetle badania ECAP. Alergia Astma Immunologia 2009; 14: 27-34.

7. Samoliński B, Sybilski AJ, Raciborski F, et al. Prevalence of rhinitis in polish population according to the ECAP (Epidemiology of Allergic Disorders in Poland) study. Otolaryngol Pol 2009; 63: 324-30.

8. Stankiewicz-Choroszucha B, Wawrzyniak Z, Lipiec A, et al. Consequences of smoke inhalation in the „Epidemiology of Allergic Diseases in Poland” project (ECAP). Ann Agric Environ Med 2011; 18: 420-8.

9. Sybilski AJ, Raciborski F, Lipiec A, et al. Atopic dermatitis is a serious health problem in Poland. Epidemiology studies based on the ECAP study. Adv Dermatol Allergol 2015; 32: $1-10$.

10. Eriksson NE. Allergy screening with Phadiatop and CAP Phadiatop in combination with a questionnaire in adults with asthma and rhinitis. Allergy 1990; 45: 285-92.

11. Bousquet J, Khaltaev N, Cruz AA, et al. Allergic rhinitis and its impact on asthma (ARIA) 2008 update (in collaboration with the World Health Organization, GA(2)LEN and AllerGen). Allergy 2008; 63 Suppl 86: 8-160.

12. Available at: www.ecap.pl (Access 28.07.2016).

13. Samoliński B, Raciborski F, Lipiec A, et al. Epidemiologia chorób alergicznych w Polsce (ECAP). Pol J Allergol 2014; 1: 10-8.

14. Zieliński W. Wybrane testy statystyczne. Fundacja Rozwój SGGW, Warsaw 1999.

15. Antó JM, Sunyer J, Basagańa X, et al. Risk factors of newonset asthma in adults: a population-based international cohort study. Allergy 2010; 65: 1021-30.

16. Jaakkola MS, leromnimon A, Jaakkola JJ. Are atopy and specific IgE to mites and molds important for adult asthma? J Allergy Clin Immunol 2006; 117: 642-8.

17. Roduit C, Frei R, Depner M, et al. Increased food diversity in the first year of life is inversely associated with allergic diseases. J Allergy Clin Immunol 2014; 133: 1056-64.

18. Wegienka G, Havstad S, Kim H, et al. Subgroup differences in the associations between dog exposure during the first year of life and early life allergic outcomes. Clin Exp Allergy 2017; 47: 97-105.

19. Ciprandi G, Comite P, Ferrero F, et al. Serum allergen-specific IgE, allergic rhinitis severity, and age. Rhinology 2016; 54 : 231-8.

20. Zolkipli Z, Roberts G, Cornelius V, et al. Randomized controlled trial of primary prevention of atopy using house dust mite allergen oral immunotherapy in early childhood. J Allergy Clin Immunol 2015; 136: 1541-7.

21. Ciprandi G, Incorvaia C, Puccinelli P, et al. The polysensitization as a challenge for the allergist: the suggestions provided by the POLISMAIL studies. Expert Opin Biol Ther 2011; 11: 715-22.

22. Rolinck-Werninghaus C, Keil T, Kopp M, et al. Specific IgE serum concentration is associated with symptom severity in children with seasonal allergic rhinitis. Allergy 2008; 63: 1339-44. 